\title{
Validation of chironomid-inferred temperature reconstructions in Iceland: the potential for reconstructing quantitative changes in Holocene climate
}

\author{
Naomi Holmes, Exeter
}

\section{Introduction}

Concern over the extent to which anthropogenic activity has forced recent changes in climate and could contribute to future climatic change has been the focus of many recent studies (INTERgOVERnMENTAL PANEL ON Climate Change, IPCC, 2001, 2007). To try to evaluate this it is essential to understand past natural climatic variability. Instrumental meteorological records are only available for c. 150 years so it is necessary to obtain proxy climate data for periods prior to this in order to validate climate models that predict climatic changes. The study of biological proxy data also has the potential to provide information on the possible ecological effects any future climatic changes may have on lake ecosystems and their biota (e.g. QuINLAN et al. 2005).

Chironomids (Insecta; Diptera; Chironomidae) are a biological proxy frequently used in palaeoenvironmental and palaeoecological studies. The chitinous head capsules (see Figure 1) of chironomid larvae preserve in lake sediments and can be isolated from the sediment and analysed to provide information about past environmental conditions within the lake and local environment (Porinchu \& MacDonald 2003). The potential of subfossil chironomids to reconstruct past changes in temperature has been demonstrated by a number of Lateglacial studies undertaken in the northern hemisphere (e.g. BEDFORD et al. 2004; BrooKs \& BIRKs 2000a, b; PORINCHU et al. 2003). Recently, chironomid studies have been used to reconstruct Holocene palaeoclimatic changes (e.g. KUREK et al. 2004; LANGDON et al. 2004; Velle et al. 2005a); however, the magnitude of temperature change in the Holocene is much smaller than over the last Glacial - Interglacial Transition, and much debate surrounds the use of subfossil chironomids to produce reliable temperature reconstructions for this period (e.g. LarocQue \& Hall 2003; Velle et al. 2005b). CASEldine et al. (2003) produced the first quantitative palaeolimnological study from Iceland, using the Norwegian chironomid-mean July air temperature transfer function (BRooKs \& BIRKS 2001; unpub.) showing the potential of subfossil chironomids present in Icelandic lakes as a climate proxy. The recent development of a chironomid-inferred mean July air temperature calibration model for Iceland (CASELDINE et al. 2006; LANGDON et al.) provided the opportunity to try to evaluate and validate the technique within Iceland.

\section{Methods}

\subsection{Site selection and fieldwork}

Cores were obtained from two lakes situated in western Iceland, Baulárvallavatn and Saurarvatn, near to the meteorological station at Stykkishólmur which has the longest instrumental temperature record for Iceland (Figure 2). Baulárvallavatn is a relatively deep lake $\left(Z_{\max } 46 \mathrm{~m}\right)$ situated at $193 \mathrm{~m}$ above sea level, while Saurarvatn has a maximum depth of $14.3 \mathrm{~m}$ and is located close to sea level. The study sites were initially selected and sampled during the development of the Icelandic chironomid training set (LANGDON et al.). Detailed bathymetries were produced and short cores obtained from each lake (Figure 3). Cores were taken using a Renberg corer (RENBERG 1991) and subsampled in the field. At Baulárvallavatn the cores were taken from a relatively flat bottomed part of the lake at c. $20 \mathrm{~m}$ depth as the lake bottom shelved quite steeply in deeper areas. Other data from Baulárvallavatn suggest that the depth of sampling location does not influence the chironomid data obtained (Holmes 2006). At Saurarvatn, the core was obtained from the largest of the three basins in the lake. Information about the physical characteristics of the lakes is detailed in Table 1.

\subsection{Laboratory methods}

Sedimentological and dating analyses. A subsample from each sample was analysed for $\mathrm{CN}$ (total \% total \% N and C:N) using a Carlo Erba Elemental Analyser model NA2500. Particle size was analysed using a Saturn DigiSizer, and magnetic susceptibility measured using a Bartington MS2 Susceptibility system. Radioisotopic analyses were carried out at the University of Exeter and National Oceanography Centre, Southampton. Samples were analysed for ${ }^{210} \mathrm{~Pb},{ }^{214} \mathrm{~Pb}$ (Southampton), ${ }^{226} \mathrm{Ra}$ (Exeter), and ${ }^{137} \mathrm{Cs}$ by gamma spectrometry in order to derive chronological information about the lake sediments (APPLEBy 2001).

Chironomid analysis. Samples were prepared for chironomid analysis using standard techniques with ultrasound treatment used to clean the head capsules in order to aid identification (LANG et al. 2003; WALKER 2001). Chironomids were identified using Oliver \& Roussel (1983), Wiederholm (1983), RieradeVAll \& Brooks (2001), and Brooks' Tanytarsini identification key (unpub.) and taxonomy has been updated following Brooks et al. (2007). Chironomid diagrams were produced using TGView 2.0.2 (Grimm 2004). Chirono- 

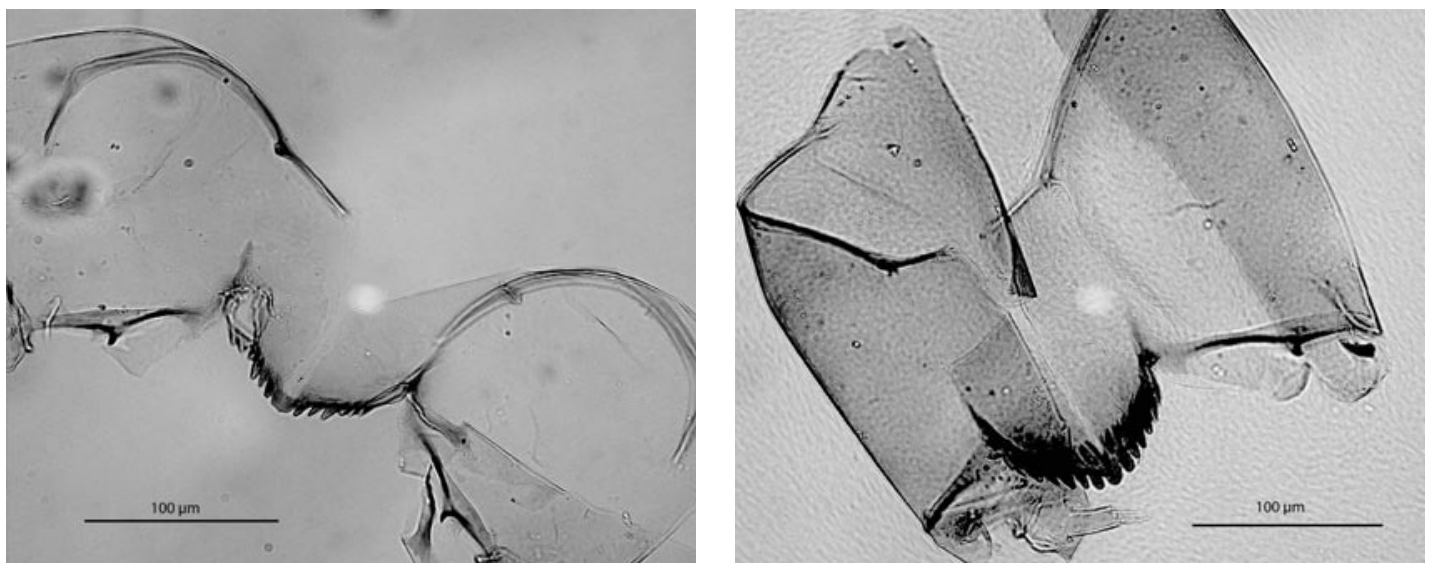

Fig. 1: Two subfossil chironomid head capsules: Hydrobaenus (left), Orthocladius type I (right) Zwei subfossile Chironomid-Kopfkapseln: Hydrobaenus (links), Orthocladius Typ I (rechts) Deux capsules céphaliques subfossiles de chironomides: Hydrobaenus (gauche), Orthocladius type I (droite) Photos: N. Holmes

mid assemblage data were analysed using CANOCO (Ter Braak \& Šmilauer 2002). Chironomid-inferred temperatures (C-ITs) were produced by applying the chironomid-inferred mean July air temperature transfer function for Iceland $\left(\mathrm{r}^{2}=0.66\right.$, RMSEP $=1.10^{\circ} \mathrm{C}$; LANGDON et al.) to each sample using C2 (JugGins 2003).

\section{Results}

\subsection{Core chronologies}

${ }^{137} \mathrm{Cs}$ and ${ }^{210} \mathrm{~Pb}$ provided chronologies for the cores from Baulárvallavatn and Saurarvatn. The core from Baulárvallavatn covers a period of about 130 years (back to c.1870 AD). A peak in ${ }^{137} \mathrm{Cs}$ at $9.25 \mathrm{~cm}$ represents the 1963/64 fallout maximum, while the ${ }^{210} \mathrm{~Pb}$ data suggest sedimentation rates of 1-2.5 mm year ${ }^{-1}$ (410 years $\mathrm{cm}^{-1}$ ), with higher sedimentation rates at the top of the core, perhaps due to a relative lack of compaction at the top of the core. There is close agreement between the ${ }^{137} \mathrm{Cs}$ and ${ }^{210} \mathrm{~Pb}$ ages which suggests the ${ }^{210} \mathrm{~Pb}$ chronology is accurate. The core from Saurarvatn is thought to represent the period c.1950-2003 with a clearly defined ${ }^{137} \mathrm{Cs}$ peak representing the $1963 / 64$ weapon's fallout maximum at a depth of $20.5 \mathrm{~cm}$. The ${ }^{210} \mathrm{~Pb}$ data suggest a linear sedimentation rate of $0.2 \mathrm{~mm}$ year ${ }^{-1}\left(5\right.$ years $\left.\mathrm{cm}^{-1}\right)$ between $14-23 \mathrm{~cm}$ and that the upper $14 \mathrm{~cm}$ covers the period 1995-2003, with a very high average accumulation rate of $1.75 \mathrm{~cm}_{\text {year }}{ }^{-1}$ in this period, probably due to increased inputs of sediment from the lake catchment.

\subsection{Sedimentological analyses}

Values of both \% $\mathrm{C}$ and $\% \mathrm{~N}$ (Figure $4 \mathrm{a}$ ) are relatively low in Baulárvallavatn, reflecting the low productivity of the lake, and allochthonous origin of most of the sediment within the lake. Increases in both elements in the upper sediments are thought to be due to the greater proportion of undecomposed organic matter found here, but possibly reflect nutrient increases within the lake/catchment. The levels of $\% \mathrm{~N}$ and $\% \mathrm{C}$ (Figure $4 \mathrm{~b}$ ) are higher in Saurarvatn reflecting its slightly more productive nature. $\% \mathrm{~N}$ shows an increasing trend up the core, while $\% \mathrm{C}$ values remain fairly constant. Variability in both elements near the top of the core is thought to reflect inwash from the catchment which is responsible for the higher sedimentation rates in this part of the core.

\subsection{Chironomid assemblages}

At Baulárvallavatn the chironomid stratigraphy (Figure 4a) is dominated by Heterotrissocladius grimshawi-type, a cold stenotherm indicative of oligotrophic lakes, with values of between $40-67 \%$. A number of rheophilic taxa, such as Eukiefferiella spp. and Diamesinae, are present, which along with the Simuliidae suggest some riverine influence on the lake. At Saurarvatn Psectrocladius sordidellus-type, Chironomus anthracinus-type, and Heterotrissocladius grimshawi-type are the most common taxa present throughout the core (Figure 4b). Taxa, such as Chironomus anthracinus-type, Cricotopus sylvestris-type and Orthocladius oliveri-type, which are thought to live in more productive ecosystems where macro- 


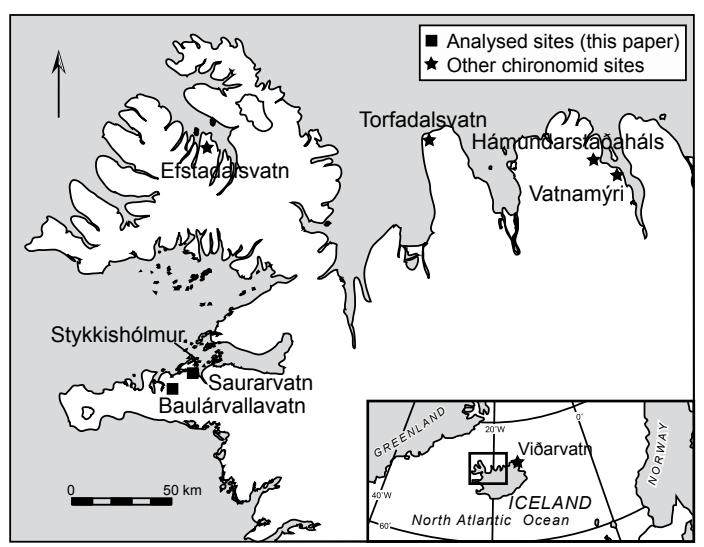

Fig. 2: Location of study sites (squares) and other sites referred to (stars): Efstadalsvatn (CASELDINE et al. 2003), Vatnamýri and Hámundarstaðaháls (CASELDINE et al. 2006), Torfadalsvatn, Viðarvatn (inset map) (AXFord et al. 2007). The location of the meteorological station at Stykkishólmur is also shown.

Untersuchungsgebiete (Kasten) und weitere Orte (gekennzeichnet mit einem Stern): Efstadalsvatn (CASELDine et al. 2003), Vatnamýri und Hámundarstaðaháls (CASELDINE et al. 2006), Torfadalsvatn, Viðarvatn (eingefügte Karte) (AxFord et al. 2007). Die Lage der meteorologischen Station bei Stykkishólmur ist ebenfalls ersichtlich.

Localisation des sites d'enquête (carrés) et des autres sites mentionnés (étoiles): Efstadalsvatn (CASELDINE et al. 2003), Vatnamýri et Hámundarstaðaháls (CASELDINE et al. 2006), Torfadalsvatn, Viðarvatn (carte en encart) (AXFORD et al. 2007). La localisation de la station météorologique de Stykkishólmur est aussi visible. Cartography: N. HoLmes

phytes are present, occur throughout the core, as do Chara oospores. Macrophytes were observed in Saurarvatn during fieldwork.

\subsection{Chironomid-inferred temperatures}

Baulárvallavatn. The chironomid-inferred temperature (C-IT) reconstruction from Baulárvallavatn shows little variation through the core, with low temperature variability $\left(0.78^{\circ} \mathrm{C}\right)$. No changes in temperature are greater than the sample specific prediction errors (SSPEs) and so are not significant statistically. The overall pattern is a slight warming trend. The CIT reconstruction is compared to the instrumental meteorological temperature record from Stykkishólmur (Figure 5a). The Stykkishólmur temperature data have been adjusted to the altitude of Baulárvallavatn (c.200 m) by applying a lapse rate of $0.65^{\circ} \mathrm{C} 100 \mathrm{~m}^{-1}$.
Both records show a cooling from 1900-c.1920 followed by a temperature increase between 1925-1940 and then decreasing temperatures until c.1960. A warming trend from the mid-1980s to mid-1990s is also evident in both records. The C-IT reconstruction consistently underpredicts the temperatures, although for every sample the meteorological temperature values fall within the SSPEs.

Saurarvatn. The range of reconstructed temperatures is $1.1{ }^{\circ} \mathrm{C}$, smaller than the mean SSPE of $1.12{ }^{\circ} \mathrm{C}$, and as a result, none of the temperature changes are significant statistically. However, when the C-IT reconstruction is plotted alongside the temperature data from Stykkishólmur (Figure 5b) it can be seen that there are many similarities between the two records. Again the C-ITs consistently underpredict the meteorological data, although the predicted values (including SSPEs), in most cases, overlap with the meteorological data values. Both records show cooling during the 1950s-1970s followed by a period of warming in the early-1980s. A temperature decrease from the late1980 s to the early-1990s is also evident in both records, and the late-1990s to early 2000s warming trend seen in the chironomid data matches very well with the instrumental data in terms of pattern and magnitude of changes.

\section{Discussion}

The comparison of the C-IT reconstructions with the Stykkishólmur meteorological data suggests that the subfossil chironomids from Iceland do respond to, and are able to successfully reconstruct the relatively small magnitude variations in temperature that have occurred during the recent period, despite the observed temperature changes in the meteorological record being close to the error limits of the chironomid-mean July air temperature calibration model. However, at present, the reconstructions produced for the two sites studied here are underpredicting actual values, although at Baulárvallavatn all the reconstructed temperatures and their SSPEs are deemed similar to the running mean of the meteorological data.

\subsection{Factors influencing the midges}

Since early work on quantitative C-IT reconstructions the question of whether midges are really responding to climate, either directly or indirectly, has been raised (Hann et al. 1992; Larocque \& Hall 2003; Velle et al. 2005a; Walker \& MatheWes 1987; Walker et al. 1992; WARNER \& HANN 1987). The data presented in this paper do suggest the chironomids are responding to and therefore reconstructing changes in past temperatures, however, as is the case in the majority of chironomid studies, multiple factors could be influ- 


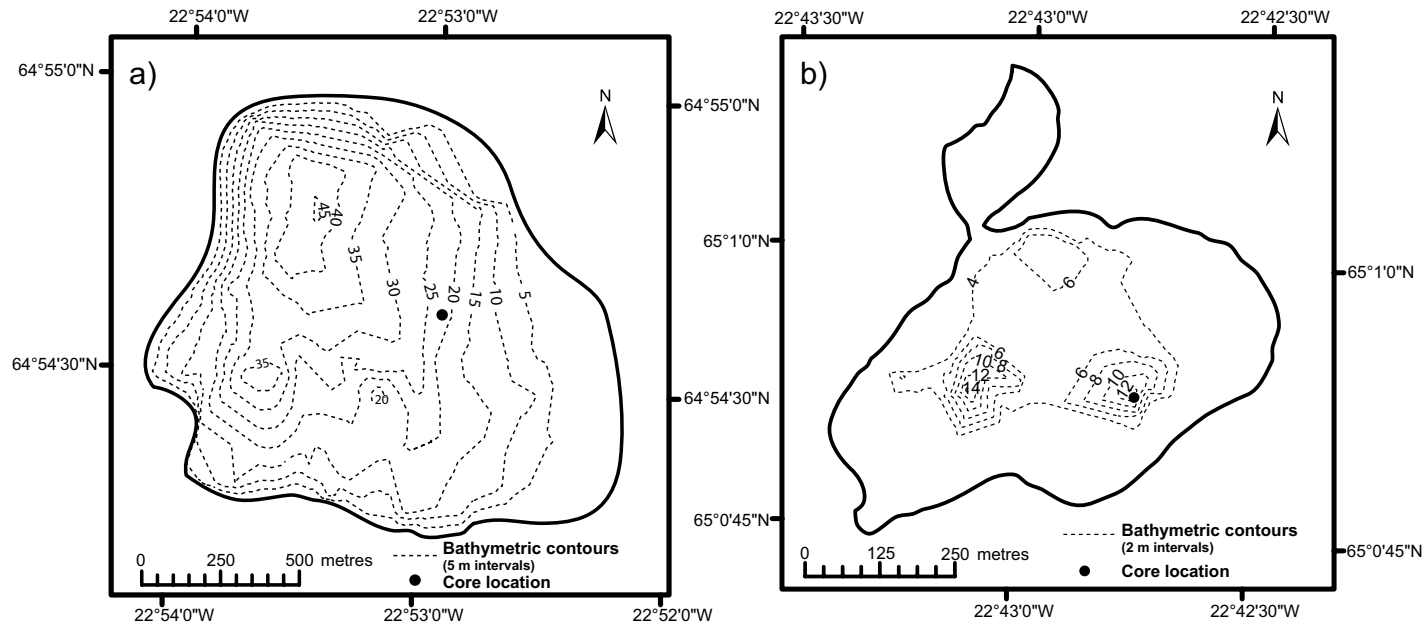

Fig. 3: Bathymetric maps of the lakes studied. Coring locations are shown: a) Baulárvallavatn, b) Saurarvatn Bathymetrische Karten der untersuchten Seen. Lage der Bohrungen: a) Baulárvallavatn, b) Saurarvatn Cartes bathymétriques des lacs étudiés. Les sites des forages sont indiqués: a) Baulárvallavatn, b) Saurarvatn Cartography: N. HoLmes

encing the midges, and as a result a multi-proxy study should be used where possible (BATTARBEe 2000). For both sites the patterns of the C-IT reconstructions are very similar to those in the meteorological data. However, over the short timescales covered by this study, it could be possible that changes in nutrient status within the lake are greater than the changes in climate, and therefore that the chironomids are responding to the changing nutrient levels (DaLton et al. 2005; VelLe et al. 2005a). The location of these two oligotrophic lakes in the west of Iceland limits the effects of anthropogenic influences on the lakes, and as a result any vari-

\begin{tabular}{|l|l|l|}
\hline & Baulárvallavatn & Saurarvatn \\
\hline Latitude $\left({ }^{\circ} \mathrm{N}\right)$ & $64^{\circ} 54^{\prime}$ & $65^{\circ} 01^{\prime}$ \\
Longitude $\left({ }^{\circ} \mathrm{W}\right)$ & $22^{\circ} 53^{\prime}$ & $22^{\circ} 43^{\prime}$ \\
Altitude $(\mathrm{m}$ asl $)$ & 193 & 11 \\
July air $\mathrm{T}\left({ }^{\circ} \mathrm{C}\right)$ & 9.62 & 10.15 \\
$($ BJöRNSSON 2003) & & \\
$\mathrm{Z}_{\text {max }}(\mathrm{m})$ & 45.6 & 14.3 \\
Surface area $\left(\mathrm{km}^{2}\right)$ & 1.6 & 0.29 \\
\hline
\end{tabular}

Tab. 1: Physical properties of the two study lakes Physikalische Eigenschaften der untersuchten Seen Propriétés physiques des deux lacs étudiés ations in nutrient levels could be seen to be a result of changing climate. Changes in $\% \mathrm{~N}$ and $\% \mathrm{C}$ in both lakes are very slight, although the uppermost samples from Baulárvallavatn show an increase in both elements. This may result from a higher proportion of undecomposed matter at the top of the core.

\subsection{Underprediction of temperatures by the chironomid data}

The C-IT reconstructions underpredict the temperatures as recorded by the meteorological data. There are a number of possible reasons for this. Baulárvallavatn and Saurarvatn occur near the upper end of the temperature gradient of the Icelandic training set (LANGDON et al.), and many transfer functions underpredict temperatures at the upper limit of the gradient covered (BROOKS \& BIRKS 2000b). This can be overcome by increasing the number of sites in the training set and the length of gradient these sites cover; this would also act to lower the error terms of the model. It is also possible that the nature of the climatic data used caused the underprediction. The climate data used in the calibration model is from the period 19611990. Post-1980, temperatures have been increasing, and using climatic data from Stykkishólmur, it is thought this could account for c. $0.5^{\circ} \mathrm{C}$ (nearly $50 \%$ ) of the underprediction (Holmes 2006).

Dalton et al. (2005) found that C-ITs for a Scottish loch were lower than those inferred from vegetation 


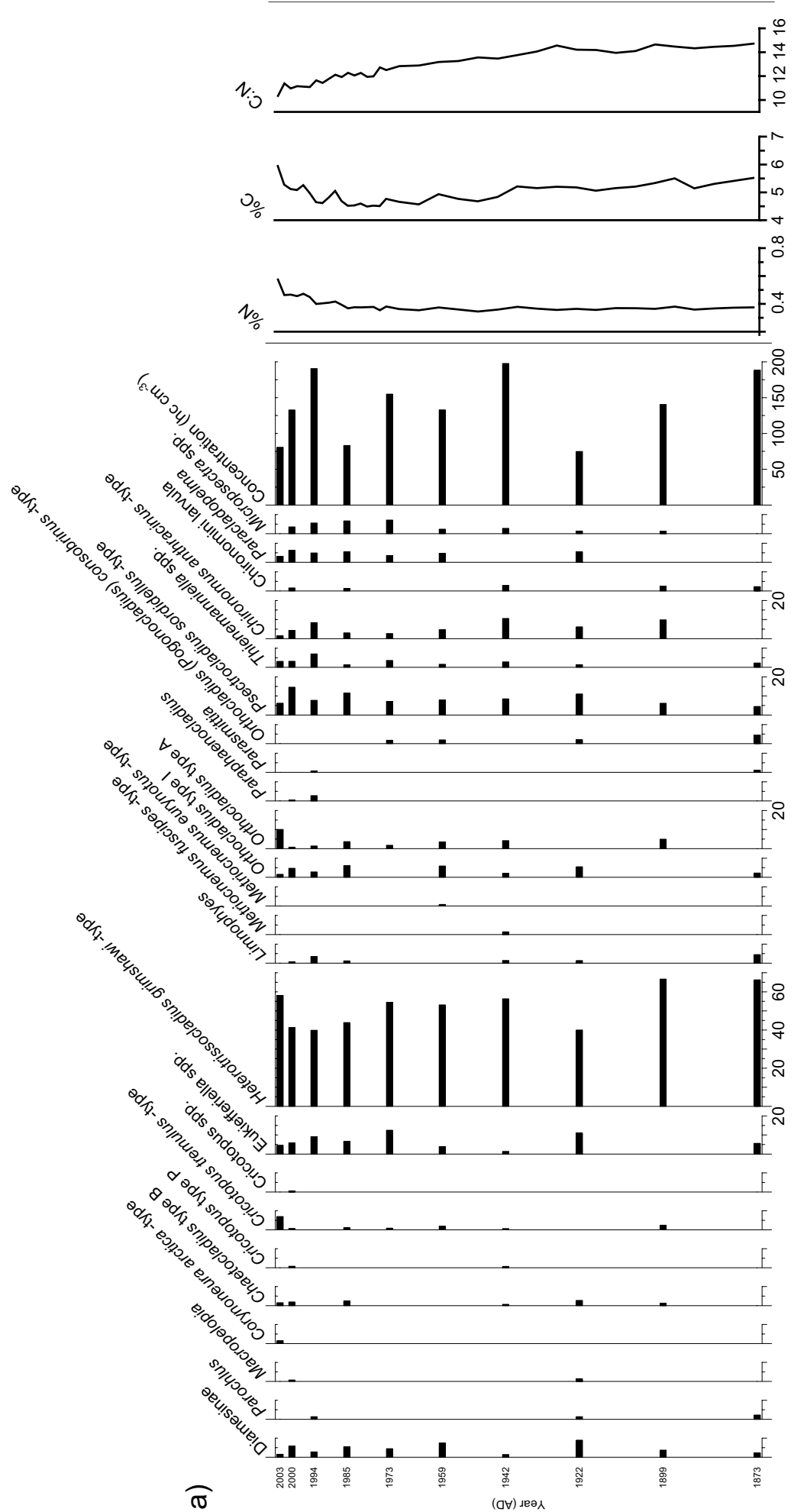




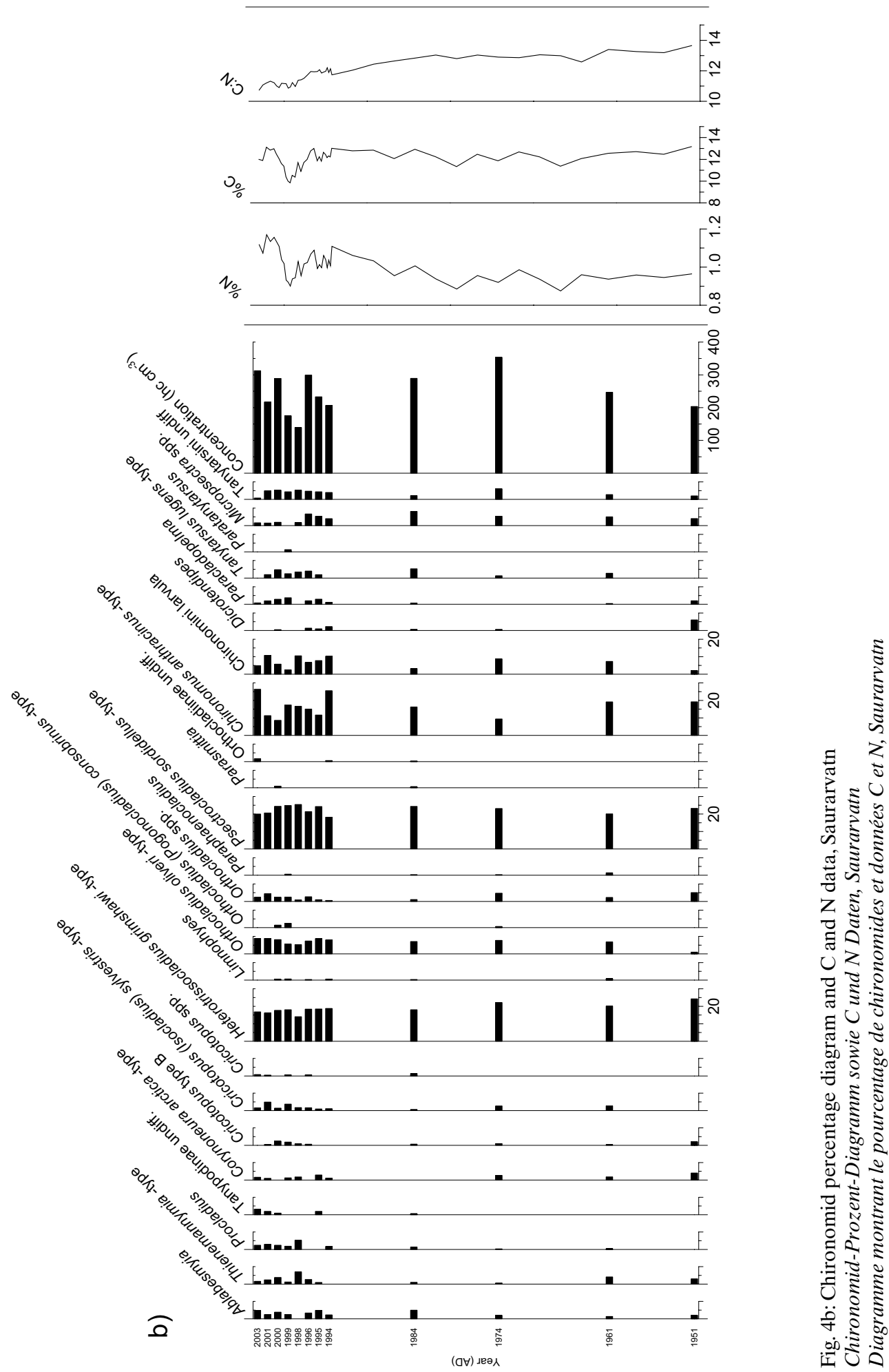



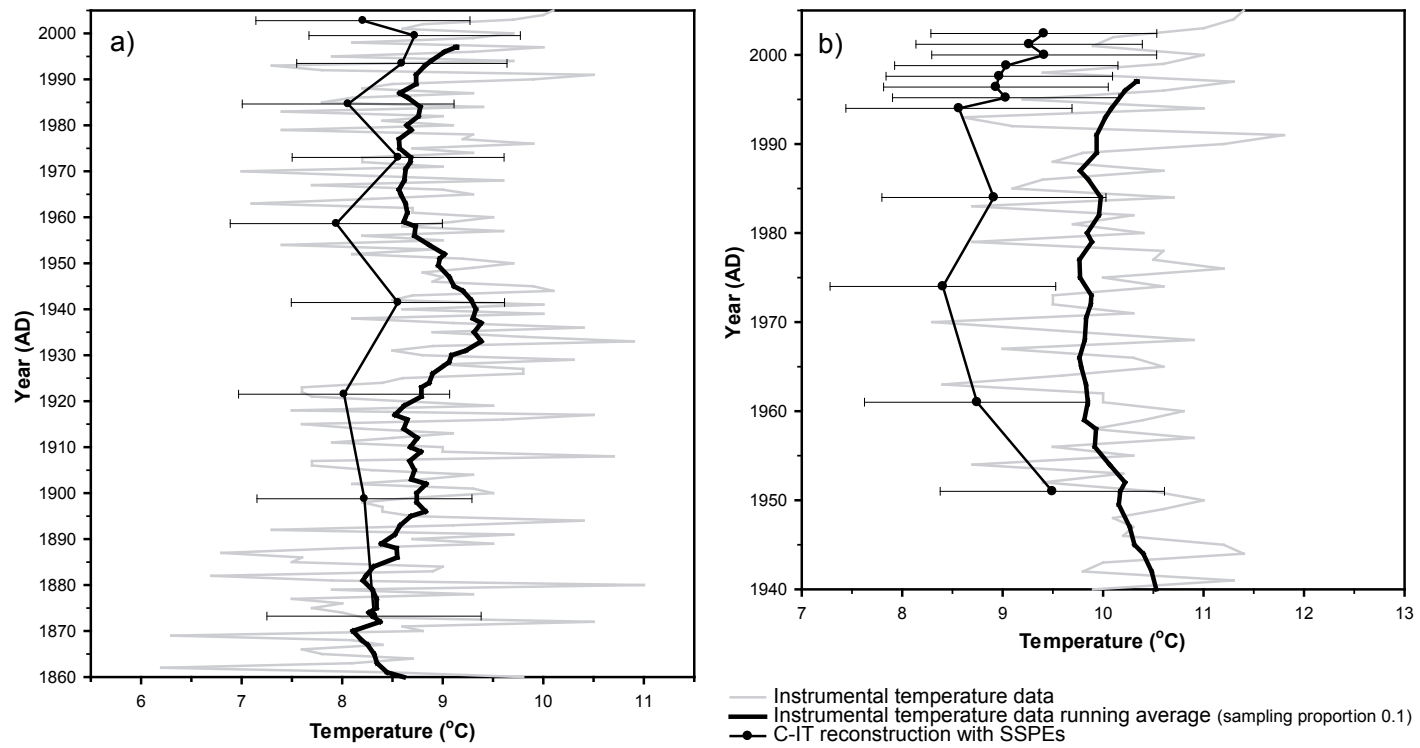

Fig. 5: Chironomid-inferred mean July air temperature reconstructions plotted alongside the meteorological July temperature data from Stykkishólmur. Error bars on the chironomid-inferred temperatures indicate SSPEs. The meteorological data in a) has had an environmental lapse rate of $0.65{ }^{\circ} \mathrm{C} 100 \mathrm{~m}^{-1}$ applied to it to account for an altitudinal difference of c. $200 \mathrm{~m}$ between Baulárvallavatn and Stykkishólmur. a) Baulárvallavatn, b) Saurarvatn Mittels Chironomid abgeleitete mittlere Lufttemperatur im Juli, aufgezeichnet entlang der meteorologischen Temperaturen im Juli in Stykkishólmur. Fehlerbalken der von Chironomid abgeleiteten Temperaturen zeigen SSPE (Sample Specific Prediction Errors) an. Die meteorologischen Daten in a) wurden durch eine Umgebungsfehlerrate von $0.65^{\circ} \mathrm{C} 100 \mathrm{~m}^{-1}$ an die Höhendifferenz von $200 \mathrm{~m}$ zwischen Baulárvallavatn und Stykkishólmur angepasst. a) Baulárvallavatn, b) Saurarvatn

Reconstruction des températures moyennes de l'air au mois de juillet déduites par les chironomides relativement aux données de température de juillet de Stykkishólmur. Les barres d'erreur des valeurs relatives aux températures déduites par les chironomides indiquent les SSPE (Sample Specific Prediction Errors). Un taux de 0,65 ${ }^{\circ}{\mathrm{C} 100 \mathrm{~m}^{-1}}^{-1}$ a été appliqué aux données météorologiques de manière à prendre en compte la différence de 200 m environ entre Baulárvallavatn et Stykkishólmur. a) Baulárvallavatn, b) Saurarvatn

reconstructions and noted that snowbeds are present in the catchment for much of the year, suggesting that summer snowmelt may keep the loch water cooler during the summer. This would lead to the presence of chironomid assemblages representative of areas with cooler mean July air temperatures (DALTON et al. 2005). At Baulárvallavatn, snowbeds are present within the catchment and melt from these might cause a slight reduction in the temperature of the lake water in relation to the air temperature. Saurarvatn, located near to sea level, is not influenced by snowbeds, so this would not account for the underprediction at this site.

Such underprediction was also seen by Granados \& Toro (2000) who found that their chironomid temperature reconstruction showed the same general trends as local meteorological data, although the actual values produced were not reliable. HeIRI et al. (2003) found that the most recent samples in a core from Hintburgsee produced C-ITs that were too high, possibly due to anthropogenic impacts on the lake ecosystem; this is thought unlikely at the Icelandic sites. In contrast, a number of studies have found very little discrepancy between modern observed temperatures and C-ITs. Apart from the study by Granados \& Toro (2000), the only other example of quantitative chironomid records being compared to meteorological records is the study by LAROCQUE \& HALL (2003) in which C-IT reconstructions from four Swedish lakes were compared to local instrumental climate data. In their study, the majority of the C-ITs were considered to reconstruct relatively accurately, as in most cases the instrumental data fell within the SSPEs of the reconstructed temperatures. BROOKS \& BIRKs (2001) reconstructed the modern tem- 
perature of Lochan Uaine at $10.5^{\circ} \mathrm{C}$ while instrumental data recorded a temperature of $10.7^{\circ} \mathrm{C}$ and LANGDON et al. (2004) produced a reconstructed temperature of $14.6{ }^{\circ} \mathrm{C}$ for Talkin Tarn which compared well with the present mean July air temperature of $14.8^{\circ} \mathrm{C}$.

\subsection{Holocene timescale studies}

The data presented above suggest that the subfossil chironomids produce useful temperature reconstructions during the instrumental period. It is important to know whether this is also the case over Holocene and longer timescales, when the need to reconstruct climate is greater as there are no instrumental records available. It is possible that factors influencing the midges have changed through the Holocene (LAROcQue \& Hall 2003; Velle et al. 2005a), and it is therefore necessary to carry out some kind of validation of the C-IT reconstructions produced for the Holocene. This can be done by comparison with other terrestrial data, and also with marine and ice core data.

Chironomids from two sites in the north of Iceland, Hámundarstaðaháls and Vatnamýri (see Figure 2) were analysed and the C-IT reconstructions produced were remarkably similar both in terms of patterns and values, even though the actual chironomid assemblages present in the two sites did differ (CASELDINE et al. 2006). When the chironomid data are compared with offshore records it is also clear that the patterns and magnitude of changes are very similar in the terrestrial and marine proxy records (CASELDINE et al. 2006). AXFord et al. (2007) produced C-IT reconstructions from three sites in northern Iceland (Figure 2). The reconstructions produced similar trends although there were some differences, particularly in the late Holocene (AXFord et al. 2007). These data were compared with that from Efstadalsvatn, NW Iceland (Figure 2) and a similar pattern of Holocene temperature development was seen (AXForD et al. 2007). The fact that a number of temperature reconstructions from lakes located in different areas of Iceland are producing similar trends and magnitudes of changes in temperature suggests that the changes in chironomid assemblages are being driven by regional changes in temperature rather than by other, site specific, factors such as lake ontogeny and catchment development.

Although the validity of the Holocene sequences is supported it is difficult to evaluate the actual figures produced. New high resolution reconstructions of sea surface temperatures (SSTs) (e.g. BENDLE \& RosellMelé 2007) will provide further opportunities to evaluate Holocene timescale chironomid temperature reconstructions. SST reconstructions would be expected to show similar patterns of Holocene climate development to the chironomid sites studied, due to the near-coastal location of these sites.

\section{Conclusion}

These results suggest that subfossil chironomids can provide a reliable estimate of July air temperatures, especially temperature trends, even though the error limits of the chironomid-inferred mean July air temperature calibration model overlap with the magnitude of recent Holocene temperature changes. It is possible the error terms will be reduced by the future expansion of the training set. The chironomids seem capable of reconstructing both small magnitude temperature changes as experienced during recent times, and larger magnitude changes as experienced earlier in the Holocene. They are however best used as part of a multi-proxy, multi-site study where other proxies are able to support the relatively subtle changes inferred based on analysis of the subfossil chironomids.

\section{Acknowledgements}

Chris Caseldine, Pete Langdon and Zoë Ruiz are thanked for their help with fieldwork. Thanks to Yarrow Axford, Thóra Hrafnsdóttir and Pete Langdon for helpful discussions about Icelandic subfossil chironomids. Funding was provided by the Natural Environment Research Council (NERC) (Studentship NER/S/S/2002/10368A).

\section{References}

Appleby, P.G. (2001): Chronostratigraphic techniques in recent sediments. - In: LAST, W.M. \& J.P. SMOL (eds): Tracking environmental change using lake sediments. Basin analysis, coring, and chronological techniques. - Dordrecht: Kluwer: 171-203.

Axford, Y., Miller, G.H., Geirsdóttir, Á. \& P.G. LANGDON (2007): Holocene temperature history of northern Iceland inferred from subfossil midges. - In: Quaternary science reviews 26: 3344-3358.

BATTARBEE, R.W. (2000): Palaeolimnological approaches to climate change, with special regard to the biological record. - In: Quaternary science reviews 19:107-124.

Bedford, A., Jones, R.T., Lang, B., Brooks, S. \& J. Marshall (2004): A Late-glacial chironomid record from Hawes Water, northwest England. - In: Journal of Quaternary science 19:281-290.

Bendle, J.A.P \& A. Rosell-Melé (2007): High resolution alkenone sea surface temperature variability on the North Icelandic Shelf: implications for Nordic Seas palaeoclimatic development during the Holocene. - In: The Holocene 17: 9-24.

BJörnsson, H. (2003): The annual cycle of temperature in Iceland. - Report 03037, Reykjavík: Veðurstofa Íslands.

BrooKs, S.J. (2006): Fossil midges (Diptera: Chironomidae) as palaeoclimatic indicators for the Eurasian region. - In: Quaternary science reviews 25: 1894-1910. 
Brooks, S.J. \& H.J.B. Birks (2000a): Chironomidinferred Late-glacial air temperatures at Whitrig Bog, Southeast Scotland. - In: Journal of Quaternary science 15: 759-764.

Brooks, S.J. \& H.J.B. BIRKs (2000b): Chironomidinferred late-glacial and early-Holocene mean July air temperatures for Kråkenes Lake, western Norway. - In: Journal of palaeolimnology 23: 77-89.

Brooks, S.J. \& H.J.B. BIRKs (2001): Chironomid-inferred air temperatures from Lateglacial and Holocene sites in north-west Europe: progress and problems. - In: Quaternary science reviews 20: 1723-1741.

Brooks, S.J., Langdon, P.G. \& O. Heiri (2007): The identification and use of palaearctic Chironomidae larvae in palaeoecology. - QRA Technical guide no. 10, London: Quaternary Research Association.

Caseldine, C., Geirsdóttir, Á. \& P. Langdon (2003): Efstadalsvatn - a multi-proxy study of a Holocene lacustrine sequence from NW Iceland. - In: Journal of paleolimnology 30: 55-73.

Caseldine, C., Langdon, P. \& N. Holmes (2006): Early Holocene climatic variability and the timing and extent of the Holocene Thermal Maximum (HTM) in northern Iceland. - In: Quaternary science reviews 25: 2314-2331.

Dalton, C., Birks, H.J.B., Brooks, S.J., Cameron, N.G., Evershed, R.P., Peglar, S.M., Scott, J.A. \& R. ThompSON (2005): A multi-proxy study of lake-development in response to catchment changes during the Holocene at Lochnagar, north-east Scotland. - In: Palaeogeography, palaeoclimatology, palaeoecology 221: 175-201.

Granados, I. \& M. Toro (2000): Recent warming in a high mountain lake (Laguna Cimera, Central Spain) inferred by means of fossil chironomids. - In: Journal of limnology 59 (supplement 1): 109-119.

Grimm, E.C. (2004): TGView version 2.0.2. - Illinois State Museum, USA.

Hann, B.J., Warner, B.G. \& W.F. WARWICK (1992): Aquatic invertebrates and climate change. A comment on WALKER et al. (1991). - In: Canadian journal of fisheries and aquatic sciences 49: 1274-1276.

Heiri, O., Wick, L., VAN LeeuWen, J.F.N., VAN der KNAAP, W.O. \& A.F. LotTer (2003): Holocene tree immigration and the chironomid fauna of a small Swiss subalpine lake (Hinterburgsee, $1515 \mathrm{~m}$ asl). - In: Palaeogeography, palaeoclimatology, palaeoecology 189: 35-53.

Holmes, N. (2006): Evaluating the use of sub-fossil chironomids for the reconstruction of Holocene climate in $\mathrm{N}$ and $\mathrm{NW}$ Iceland. - Ph.D. thesis, University of Exeter, Department of Geography.

Intergovernmental Panel on Climate Change (IPCC), Houghton, J.T., Ding, Y., Griggs, D.J., Noguer, M., VAn der Linden, P.J., Dai, X., Maskell, K. \& C.A. Johnson (eds) (2001): Climate change 2001. The scientific basis. - Contribution of Working Group 1 to the Third Assessment Report of the Intergovern- mental Panel on Climate Change. - Cambridge: Cambridge University Press.

Intergrovernmental Panel on Climate Change (IPCC), Solomon, S., Qin, D., Manning, M., Marquis, M., Averyt, K., Tignor, M.M.B., Miller, Jr., H.L. \& Z. CHEN (eds) (2007): Climate change 2007. The physical science basis. - Contribution of Working Group 1 to the Fourth Assessment Report of the Intergovernmental Panel on Climate Change. - Cambridge: Cambridge University Press, http://ipcc-wg1.ucar.edu/wg1/ wg1-report.html.

JugGins, S. (2003): C2 data analysis. Version 1.4.2. - http://www.campus.ncl.ac.uk/staff/Stephen.Juggins/ software.htm.

Kurek, J., Cwynar, L.C. \& R.W. Spear (2004): The 8200 cal yr BP cooling event in eastern North America and the utility of midge analysis for Holocene temperature reconstructions. - In: Quaternary science reviews 23: 627-639.

LANG, B., BedFord, A.P., Richardson, N. \& S.J. Brooks (2003): The use of ultra-sound in the preparation of carbonate and clay sediments for chironomid analysis. - In: Journal of paleolimnology 30: 451-460.

LAngdon, P.G., Barber, K.E. \& S.H. Lomas-Clarke (2004): Reconstructing climate and environmental change in northern England through chironomid and pollen analyses: evidence from Talkin Tarn, Cumbria. - In: Journal of paleolimnology 32: 197-213.

Langdon, P.G., Holmes, N. \& C.J. Caseldine: Environmental controls on modern chironomid faunas from NW Iceland and implications for reconstructing climate change. - In: Journal of paleolimnology (in press).

Larocque, I. \& R.I. Hall (2003): Chironomids as quantitative indicators of mean July air temperature: validation by comparison with century-long meteorological records from northern Sweden. - In: Journal of paleolimnology 29: 475-493.

Oliver, D.R. \& M.E. Roussel (1983): The insects and arachnids of Canada. Part 11: The genera of larval midges of Canada. - Ottawa: Agriculture Canada Publication.

Porinchu, D.F. \& G.M. MacDonald (2003): The use and application of freshwater midges (Chironomidae: Insecta: Diptera) in geographical research. - In: Progress in physical geography 27: 378-422.

Porinchu, D.F., MacDonald, G.M., Bloom, A.M. \& K.A. Moser (2003): Late Pleistocene and early Holocene climate and limnological changes in the Sierra Nevada, California, USA, inferred from midges (Insecta: Diptera: Chironomidae). - In: Palaeogeography, palaeoclimatology, palaeoecology 198: 403-422.

Quinlan, R., Douglas, M.S.V.\& J.P. Smol (2005): Food web changes in arctic ecosystems related to climate warming. - In: Global change biology 11: 1381-1386. RENBERG, I. (1991): The HON-Kajak sediment corer. - In: Journal of paleolimnology 6:167-170. 
Rieradevall, M. \& S.J. Brooks (2001): An identification guide to subfossil Tanypodinae larvae (Insecta: Diptera: Chironomidae) based on cephalic setation. - In: Journal of paleolimnology 25: 81-99.

Ter BraAk, C.J.F \& P. Šmilauer (2002): CANOCO Reference manual and CanoDraw for Windows user's guide: software for Canonical Community Ordination (version 4.5). - New York: Microcomputer Power.

Velle, G., Brooks, S.J., Birks, H.J.B. \& E. Willassen (2005a): Chironomids as a tool for inferring Holocene climate: an assessment based on six sites in southern Scandinavia. - In: Quaternary science reviews 24: 1429-1462.

Velle, G., Larsen, J., Eide, W., Peglar, S.M. \& Birks, H.J.B. (2005b): Holocene environmental history and climate of Råtåsjøen, a low-alpine lake in south-central Norway. - In: Journal of paleolimnology 33: 129153.

WALKer, I.R. (2001): Midges: Chironomidae and related diptera. - In: SMoL, J.P., BIRKs, H.J.B. \& W. LAST (eds): Tracking environmental change using lake sediments. Volume 4: Zoological indicators. - Dordrecht: Kluwer: 43-66.

Walker, I.R. \& R.W. Mathewes (1987): Chironomids, lake trophic status and climate. - In: Quaternary research 28: 431-437.

WAlKer, I.R., EngSTrom, D.R. \& H.J.B. Birks (1992): Aquatic invertebrates, climate, scale, and statistical hypothesis testing: a response to HANN, WARNER and WARwick. - In: Canadian journal of fisheries and aquatic sciences 49: 1276-1280.

WARNER, B.G. \& B.J. HANN (1987): Aquatic invertebrates as palaeoclimatic indicators? - In: Quaternary research 28: 427-430.

Wiederholm, T. (ed.) (1983): Chironomidae of the Holarctic region. Keys and diagnoses. Part I: Larvae. In: Entomologica scandinavica, supplement 19:1-457.

\footnotetext{
Abstract: Validation of chironomid-inferred temperature reconstructions in Iceland: the potential for reconstructing quantitative changes in Holocene climate

Subfossil chironomids in short cores from two lakes in western Iceland were analysed and a chironomidmean July air temperature transfer function applied to produce chironomid-inferred temperature reconstructions for the recent past. These reconstructions were compared with local meteorological data in order to evaluate the technique in Iceland. The chironomidinferred temperature reconstructions showed similar patterns and magnitudes of change to those recorded in the instrumental data, but the chironomid temperature reconstructions slightly underpredicted the observed temperatures. This suggests that the chironomids are able to reconstruct sequence trends of temperature change although the accuracy of the actual figures produced needs to be addressed. Subfossil
}

chironomids in Iceland can be used to reconstruct the relatively small magnitude temperature changes of the last few hundred years, and also the larger magnitude changes experienced earlier in the Holocene.

Keywords: Iceland, subfossil chironomid, palaeolimnology, climate, Holocene

\section{Zusammenfassung: Mit Hilfe von Chironomiden abgeleitete Temperaturrekonstruktionen in Island: quantitative Rekonstruktion von holozänen Umwelt- veränderungen \\ Subfossile Chironomide aus kurzen Bohrkernen aus} zwei Seen im Westen Islands wurden analysiert. Eine Chironomid-mittlere Juli-Temperatur-Transferfunktion wurde angewendet, um Temperaturrekonstruktionen für die jüngere Vergangenheit zu erstellen. Diese Rekonstruktionen wurden mit lokalen meterorologischen Daten verglichen, um die in Island angewendeten Techniken zu analysieren. Die mittels Chironomid abgeleiteten Temperaturrekonstruktionen zeigen ähnliche Muster und Schwankungen wie die instrumentell erhobenen Daten, wobei die Chironomid-Temperaturrekonstruktionen die beobachteten Temperaturen leicht unterschätzen. Dies deutet darauf hin, dass es möglich ist, durch Chironomide Trends der Temperaturveränderung $\mathrm{zu}$ rekonstruieren, obwohl die Genauigkeit der aktuell produzierten Zahlen angepasst werden muss. Subfossile Chironomide in Island können für die Rekonstruktion von relativ kleinen Temperaturschwankungen der letzten Jahrhunderte verwendet werden und ebenfalls für grössere Schwankungen im früheren Holozän.

Schlüsselwörter: Island, Subfossiles Chironomid, Paläolimnologie, Klima, Holozän

\section{Résumé: Validation des reconstructions de tempé- ratures basées sur les chironomides en Islande: un potentiel de reconstruction des changements climati- ques holocènes}

Des chironomides subfossiles extraits de forages peu profonds provenant de deux lacs de l'ouest islandais ont été analysés. Une fonction de transfert basée sur la température de l'air moyenne du mois de juillet établie par les chironomides a été appliquée de manière à produire des reconstructions de températures pour le passé récent. Ces reconstructions ont été comparées aux données météorologiques locales dans le but de tester la technique en Islande. Ces reconstructions basées sur les chironomides montrent des évolutions et des magnitudes de changement similaires à celles enregistrées par les instruments de mesure, cependant les reconstructions sous-estiment légèrement les températures observées. Cela suggère que les chironomides permettent de reconstruire des évolutions de séquence de changement de température, bien que la 
précision des résultats produits nécessite d'être questionnée. Les chironomides subfossiles d'Islande peuvent être utilisés pour reconstruire les changements climatiques de faible magnitude de ces dernières centaines d'années ou des périodes plus anciennes de l'Holocène.

Mots-clés: Islande, chironomides subfossiles, paléolimnologie, climat, Holocène

Dr. Naomi Holmes, Department of Geography, University of Exeter in Cornwall, Treliever Road, Penryn, Cornwall, TR10 9EZ, United Kingdom.

N.Holmes@ex.ac.uk

Manuskripteingang/received/manuscrit entré le 25.9.2007

Annahme zum Druck/accepted for publication/accepté pour l'impression: 6.3 .2008 